\title{
Juglans mandshurica Maxim extracts exhibit antitumor activity on HeLa cells in vitro
}

\author{
NIAN XIN ${ }^{1}$, MURTAZA HASAN $^{1}, \mathrm{WEI} \mathrm{LI}^{2}$ and YAN LI ${ }^{1}$ \\ ${ }^{1}$ School of Life Science, Beijing Institute of Technology, Beijing 100081; \\ ${ }^{2}$ The First Hospital of Jilin University, Changchun, Jilin 130021, P.R. China
}

Received June 8, 2013; Accepted January 30, 2014

DOI: $10.3892 / \mathrm{mmr} .2014 .1979$

\begin{abstract}
The present study examined the potential application of Juglans mandshurica Maxim extracts (HT) for cancer therapy by assessing their anti-proliferative activity, reduction of telomerase activity, induction of apoptosis and cell cycle arrest in $\mathrm{S}$ phase in HeLa cells. From the perspective of using HT as a herbal medicine, photomicroscopy and florescent microscopy techniques were utilized to characterize the effect of the extracts on telomerase activity and cell morphology. Flow cytometry was employed to study apoptosis and cell cycle of HeLa cells, and DNA laddering was performed. The results showed that HT inhibited cell proliferation and telomerase activity, induced apoptosis and caused S phase arrest of HeLa cells in vitro. HT inhibited HeLa cell proliferation significantly, and the highest inhibition rate was $83.7 \%$. A trap-silver staining assay showed that HT was capable of markedly decreasing telomerase activity of HeLa cells and this inhibition was enhanced in a time- and dose-dependent manner. Results of a Hoechst 33258 staining assay showed that HeLa cells treated by HT induced cell death. Through DNA agarose gel electrophoresis, DNA ladders of HeLa cells treated with HT were observed, indicating apoptosis. In conclusion, the present study demonstrated that HT exhibited anti-tumor effects comprising the inhibition of growth and telomerase activity as well as apoptosis and cell cycle arrest in HeLa cells.
\end{abstract}

\section{Introduction}

The World Health Organization has reported that cancer is a primary factor of mortality worldwide with the rate increasing daily. It is estimated that the overall number of cases is likely

Correspondence to: Professor Yan Li, School of Life Science, Beijing Institute of Technology, 5 South Zhongguancun Street, Beijing 100081, P.R. China

E-mail: leeyan@bit.edu.cn

Key words: Juglans mandshurica Maxim extracts, anti-tumor, $\mathrm{HeLa}$ cells, apoptosis, $\mathrm{S}$ phase arrest to increase by $>11$ million until 2030 . Cervical cancer is a type of cancer which is expected to increase in frequency, and is caused by the human papilloma virus that forms warts in the throat and genital area (1). Cervical cancer and other types of cancer-related mortality in females of the developing countries contribute to $>85 \%$ of the global disease burden (2). In response to this imminent challenge, a number of investigations have focused on the use of traditional medicine for cancer treatment. By developing genomic and proteomic technologies in recent years, cancer research studies have entered to a new era, and cancer is currently thought to be a genetic disease. This novel point of view requires novel diagnosis and treatment approaches. It is commonly accepted that the anti-tumor effect of cancer drugs is primarily based on the induction of apoptosis. Thus, it is of importance to determine mechanisms leading to apoptosis to investigate responses of tumor cells to herbal drugs.

Scientific investigations have indicated that the bioactive components of medicinal herbs may reduce the risk of cancer through their anti-microbial, anti-oxidant and anti-tumorigenic activity, and through their ability to directly suppress carcinogenic bioactivities (3). Juglans mandshurica Maxim is a member of the Juglandaceae plant family, has bitter bark, and is pungent. Its primary chemical constituents include juglones, flavonoids, tannins and gallic acid $(4,5)$. The bark of Juglans mandshurica Maxim exhibits detoxifying effects, improves eyesight, restores consciousness and has anti-tumor properties $(6,7)$. A previous study showed that under in vitro conditions, aqueous extracts of bark directly kill mouse sarcoma 180 (S180) cells and significantly inhibit the growth of mouse hepatoma 22 cells (8). It has been reported that juglones, some of the primary components in Juglans mandshurica Maxim extracts (HT), may extend the life of HepA mice by $95 \%$ and inhibit the growth of S180 cells by $50 \%$ in vivo. Kim et al (9) reported that bark extracts from Juglans mandshurica Maxim exhibit cytotoxic effects on the human colon cell line HT-29 and the human lung adenocarcinoma cell line A599. However, no conclusive evidence of the effect of HT on cell proliferation, activity of telomerase, apoptosis induction and cell cycle arrest of HeLa cells in vitro, or its anti-tumor mechanisms, have been reported to date. The present study aimed to investigate the anti-tumor effects and mechanisms of HT by assessing its effect on the cell cycle and apoptosis in HeLa cells. 


\section{Materials and methods}

Reagents. HT were provided by the Pharmacy Department of the School of Life Science, Beijing Institute of Technology (Beijing, China), Dulbecco's modified Eagle medium (DMEM) was purchased from GIBCO-BRL (Invitrogen Life Technologies, Carlsbad, CA, USA), fetal calf serum was obtained from Sijiqing Biological Engineering Material Co. Ltd. (Hangzhou, China) and Trypsin (1:250) and MTT were supplied by Amresco Company (Solon, OH, USA).

Preparation of HT. Crude HT was provided by the Pharmacy Department of the School of Life Science, Beijing Institute of Technology (Beijing, China). For further isolation of pure juglone, the dry powder was extracted in 95\% ethanol 3 times for $1 \mathrm{~h}$ at a time and the ethanolic extract was evaporated to dryness using a rotary evaporator at $60^{\circ} \mathrm{C}$. The residue was dissolved in a 10 -fold amount of petroleum ether 3 times. To this extract, $2 \% \mathrm{Na}_{2} \mathrm{CO}_{3}$ was added until $\mathrm{pH} 9.0$ was reached, and the mixture was filtered. Hydrochloric acid was added to the filtrate to adjust the $\mathrm{pH}$ to 4.0 , and the mixture was filtered. The precipitate was collected, neutralized and dried at $60^{\circ} \mathrm{C}$. The dried product was HT. Juglone was identified as the primary active component. Chromatographic experiments were performed on an Alltima $\mathrm{C}_{18}$ column $(4.6 \times 250 \mathrm{~mm}, 5 \mu \mathrm{m})$ where the mobile phase was methanol and water (70:30), the detection wavelength was $261 \mathrm{~nm}$, the column temperature was $27^{\circ} \mathrm{C}$ and the flow rate was $1.0 \mathrm{ml} / \mathrm{min}$.

HT extracts were purified by High-performance liquid chromatography (HPLC). The results showed a single peak at a retention time of $9.12 \mathrm{~min}$ as shown in Fig. 1B, and the purity of the peak was determined to be $99.5 \%$. It was compared with standard HPLC peak of juglone as shown in Fig. 1A. Thus, the compound was purified by HPLC separation under the aforementioned, optimized conditions, and its chemical structure is shown in Fig. 2.

Cell culture. HeLa cells were obtained from the College of Life Science and Technology, Beijing Normal University (Beijing, China). Cells were cultured in DMEM medium containing $10 \%$ fetal calf serum in an incubator at $37^{\circ} \mathrm{C}$, with $5 \% \mathrm{CO}_{2}$ and saturated humidity. The cells were studied at logarithmic growth phase.

Inhibition of cell proliferation by HT. Cytotoxicity was assessed using the MTT assay. HeLa cells, at logarithmic growth phase, were counted using the trypan blue exclusion method. The cell density was adjusted to $1.0 \times 10^{7}$ cells $/ 1$ with DMEM medium. Cells were inoculated into 96-well plates at $190 \mu \mathrm{l} /$ well and incubated at $37^{\circ} \mathrm{C}, 5 \% \mathrm{CO}_{2}$ and $100 \%$ humidity for $12 \mathrm{~h}$. DMEM (10 $\mu \mathrm{l})$ containing specific concentrations of HT was added into each well separately, and each group was repeated in 5 wells. A negative (cells + medium without HT) and positive control (cisplatin) were also designed. The nine final concentrations of HT were 10, 20, 50, 100, 200, 400, 600, 800 and $1,000 \mu \mathrm{g} / \mathrm{ml}$. Cells were cultured for $24 \mathrm{~h}$ with HT. Subsequently, an MTT assay $(5 \mathrm{mg} / \mathrm{ml}, 20 \mu \mathrm{l} /$ well for $4 \mathrm{~h})$ was used to detect the inhibitory effect of HT. Optical density values were detected at $570 \mathrm{~nm}$ to obtain the $\mathrm{IC}_{50}$ value.
A
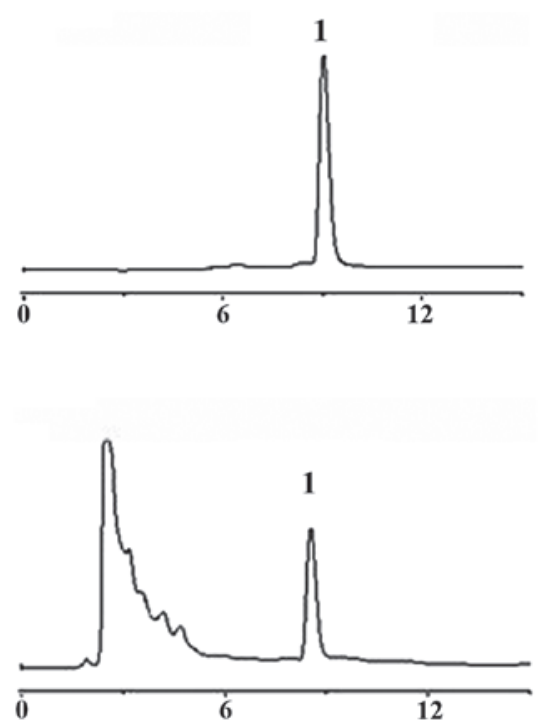

Figure 1. Analytical high-performance liquid chromatography of juglone. Chromatograms of (A) a standard sample of juglone and (B) juglone in Juglans mandshurica Maxim extracts. Chromatographic experiments were performed on Alltima $\mathrm{C}_{18}$ column $(4.6 \times 250 \mathrm{~mm}, 5 \mu \mathrm{m})$, mobile phase was methanol and water (70:30), detection wavelength was $261 \mathrm{~nm}$, column temperature was $27^{\circ} \mathrm{C}$ and flow rate was $1.0 \mathrm{ml} / \mathrm{min}$.

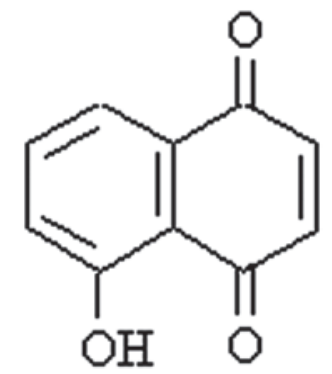

Figure 2. Chemical structure of juglone.

Effect of HT on the necrosis of HeLa cells assessed using fluorescence staining. HeLa cells in were seeded into 6-well plates, allowed to attach, and treated with HT for $48 \mathrm{~h}$. Cells were fixed in 4\% paraformaldehyde for $20 \mathrm{~min}$ at a ratio of 3:1, followed by staining with Hoechst $33342(10 \mu \mathrm{g} / \mathrm{ml})$ for $30 \mathrm{~min}$. Following mounting with glycerol, images were captured by fluorescent microscopy (BX60; Olympus Corporation, Tokyo, Japan).

Assessment of apoptosis in HeLa cells using DNA agarose gel electrophoresis. HeLa cells treated with HT for $48 \mathrm{~h}$ were trypsinised and collected by centrifugation at 4,000 $\mathrm{x}$ g for $5 \mathrm{~min}$ and DNA was extracted with phenol. Following the addition of $10 \mu \mathrm{l}$ of the sample into $1 \%$ agarose gel with ethidium bromide $(0.5 \mathrm{mg} / \mathrm{ml})$ and electrophoresis, images were captured by ultraviolet transillumination.

Effect of HT on the cell cycle of HeLa cells assessed using flow cytometry. HeLa cells $\left(2 \times 10^{5}\right.$ cells/well) were cultured in 6 -well plates for $12 \mathrm{~h}$. The cells were incubated for 24 and $48 \mathrm{~h}$ with 300 and $600 \mu \mathrm{g} / \mathrm{ml} \mathrm{HT}$, and were then centrifuged at $250 \mathrm{x}$ g for $5 \mathrm{~min}$ and washed with PBS. Cells were fixed with $70 \%$ ethanol for $12 \mathrm{~h}$ at $4^{\circ} \mathrm{C}$, and centrifugation and washing 
Table I. Inhibitory effect of HT on the proliferation of HeLa cells.

\begin{tabular}{|c|c|c|c|c|c|}
\hline \multirow[b]{2}{*}{ Group } & \multirow[b]{2}{*}{ Dose $(\mu \mathrm{g} / \mathrm{ml})$} & \multicolumn{2}{|c|}{ Optical density value } & \multicolumn{2}{|c|}{ Inhibition rate $(\%)$} \\
\hline & & $/ 24 \mathrm{~h}$ & $/ 48 \mathrm{~h}$ & $/ 24 \mathrm{~h}$ & $/ 48 \mathrm{~h}$ \\
\hline Control & 0 & $0.378 \pm 0.039$ & $0.642 \pm 0.021$ & - & - \\
\hline Cisplatin & 25 & $0.078 \pm 0.008^{c}$ & $0.065 \pm 0.008^{c}$ & 79.6 & 89.9 \\
\hline \multirow[t]{9}{*}{$\mathrm{HT}$} & 10 & $0.334 \pm 0.015^{\mathrm{a}}$ & $0.605 \pm 0.018$ & 11.7 & 3.9 \\
\hline & 20 & $0.302 \pm 0.026^{b}$ & $0.531 \pm 0.017^{\mathrm{b}}$ & 20.1 & 15.6 \\
\hline & 50 & $0.276 \pm 0.016^{\mathrm{b}}$ & $0.436 \pm 0.029^{c}$ & 27.1 & 30.7 \\
\hline & 100 & $0.249 \pm 0.014^{\mathrm{b}}$ & $0.378 \pm 0.037^{b}$ & 34.3 & 39.9 \\
\hline & 200 & $0.198 \pm 0.013^{c}$ & $0.342 \pm 0.071^{\mathrm{c}}$ & 47.5 & 45.6 \\
\hline & 400 & $0.172 \pm 0.009^{c}$ & $0.300 \pm 0.062^{c}$ & 54.5 & 52.3 \\
\hline & 600 & $0.132 \pm 0.011^{\mathrm{c}}$ & $0.225 \pm 0.024^{\mathrm{c}}$ & 65.1 & 64.2 \\
\hline & 800 & $0.091 \pm 0.008^{c}$ & $0.105 \pm 0.008^{c}$ & 76.2 & 83.3 \\
\hline & 1,000 & $0.083 \pm 0.008^{c}$ & $0.078 \pm 0.008^{c}$ & 77.9 & 87.7 \\
\hline
\end{tabular}

Values are expressed as the mean \pm standard deviation $(n=5)$. Means shown by the same letter were not significantly different from each other at a level of 5\%, using one-way analysis of variance, followed by Student's two-tailed t-test for comparison between two groups. ${ }^{\mathrm{a}} \mathrm{P}<0.05$ was considered to indicate a significant difference (compared with control group, ${ }^{\mathrm{b}} \mathrm{P}<0.01,{ }^{\mathrm{C}} \mathrm{P}<0.001$ ). For example, the mean shown by the letter $\mathrm{b}$ was different from $\mathrm{c}$ means, but not different from $\mathrm{b}$ mean. In other words, the means having different letters were different from each other. HT, Juglans mandshurica Maxim extracts.

Table II. Effect of HT on the cell cycle and apoptosis of HeLa cells.

\begin{tabular}{|c|c|c|c|c|}
\hline Group & Dose $(\mu \mathrm{g} / \mathrm{ml})$ & G1 (\%) & $\mathrm{S}(\%)$ & $\mathrm{G} 2(\%)$ \\
\hline Control & - & $67.7 \pm 5.7$ & $21.2 \pm 9.7$ & $11.1 \pm 8.7$ \\
\hline HT treated for $24 \mathrm{~h}$ & 300 & $61.7 \pm 8.7^{\mathrm{a}}$ & $23.0 \pm 4.1^{\mathrm{a}}$ & $15.3 \pm 6.3^{\mathrm{a}}$ \\
\hline HT treated for $48 \mathrm{~h}$ & 300 & $47.3 \pm 10.9^{b}$ & $37.0 \pm 9.9^{b}$ & $15.7 \pm 5.9^{a}$ \\
\hline HT treated for $24 \mathrm{~h}$ & 600 & $55.4 \pm 13.8^{\mathrm{b}}$ & $28.4 \pm 9.2^{\mathrm{b}}$ & $16.2 \pm 8.2^{\mathrm{b}}$ \\
\hline HT treated for $48 \mathrm{~h}$ & 600 & $41.9 \pm 11.3^{\mathrm{b}}$ & $39.4 \pm 8.8^{b}$ & $18.7 \pm 3.9^{\mathrm{b}}$ \\
\hline
\end{tabular}

Values are expressed as the mean \pm standard deviation $(n=5)$. Means shown by the same letter were not significantly different from each other at a level of $5 \%$, using one-way analysis of variance, followed by Student's two-tailed t-test for comparison between two groups. ${ }^{\mathrm{a}} \mathrm{P}<0.05$ was considered to be significant (compared with control group, ${ }^{a} \mathrm{P}<0.05,{ }^{b} \mathrm{P}<0.01$ ). For example, the mean shown by the letter a was different from b means, but not different from a mean. In other words, the means having the different letters were different from each other. HT, Juglans mandshurica Maxim extracts.

were repeated. The DNA distribution was detected by flow cytometry (BD FACSCalibur; BD Bioscience, Franklin Lakes, NJ, USA) following the addition of $1 \mathrm{ml}$ PI staining solution to the cells at $4^{\circ} \mathrm{C}$ in the dark for $30 \mathrm{~min}$.

Telomerase activity in HeLa cells treated with HT. Total RNA was extracted from HeLa cells following treatment with different concentrations of HT for 24 and $48 \mathrm{~h}$, and quantitative polymerase chain reaction was performed. The primer sequences were as follows: Ts primer: 5'-AATCCGTCG AGCAGAGTT-3' and Cx primer: 5'-CCCTTACCCTTACCC TTACCCTAA-3'. cDNA was amplified by PCR and its product was purified by ethanol precipitation. Following the addition of $2 \mu \mathrm{l}$ sample into $12.5 \%$ non-denaturing polyacrylamide gel for electrophoresis and silver nitrate staining, the image was immediately captured using a gel imaging system (BIO-BEST200M, SIM International Group Co, Ltd., Newark, DE, USA).
Statistical analysis. SPSS version 17.0 (SPSS Inc., Chicago, IL, USA) was used for statistical analysis. Values are expressed as the mean \pm standard deviation. Data were analyzed using a one-way analysis of variance, followed by Student's two-tailed t-test for comparison between two groups. $\mathrm{P}<0.05$ was considered to indicate a statistically significant difference.

\section{Results}

Inhibition of the cell proliferation of HeLa cells by HT. Initially, the growth inhibitory effect of HT on HeLa cells was assessed. HeLa cells were treated with various concentrations of HT (20-1,000 $\mu \mathrm{g} / \mathrm{ml})$ for 24 and $48 \mathrm{~h}$. A MTT assay was employed to assess cell proliferation. As shown in Table I, HT inhibited the cellular proliferation in a doseand time-dependent manner. Compared with the control 
A

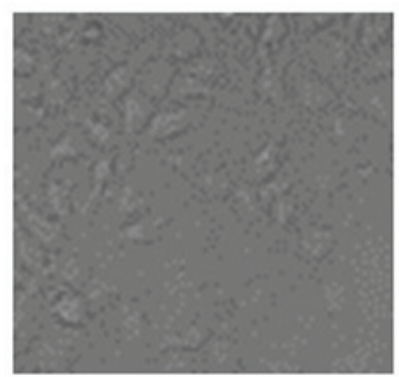

$\mathbf{0 ~ h}$

B

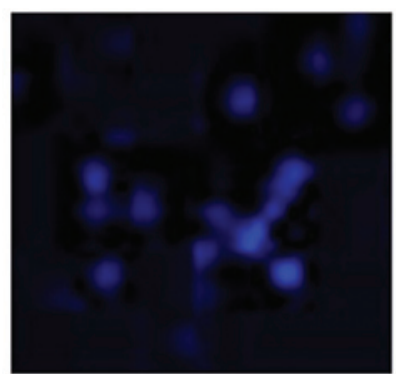

$\mathbf{0 ~ h}$

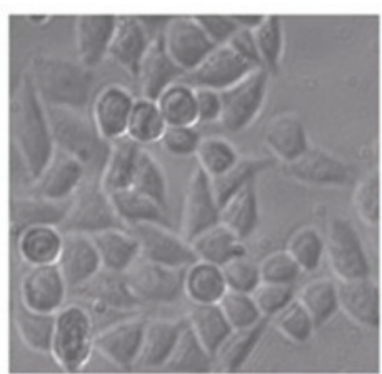

$24 \mathrm{~h}$

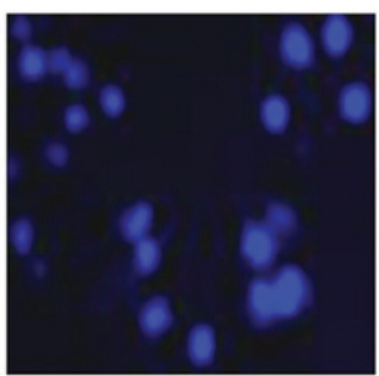

24 h

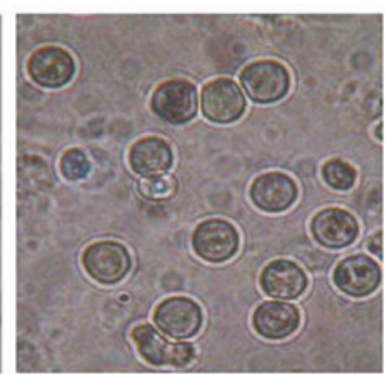

$48 \mathrm{~h}$

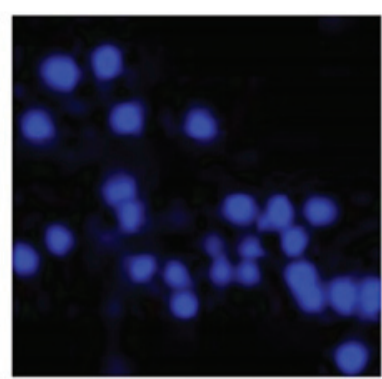

$48 \mathrm{~h}$

Figure 3. Effect of HT on the cell death of HeLa cells assessed using fluorescence staining. Cells were incubated with $600 \mu \mathrm{g} / \mathrm{ml} \mathrm{HT}$ for 0,24 and $48 \mathrm{~h}$. The quantity and fluorescence intensity of cells were observed by fluorescence microscopy. The cell death rate was quantified by the morphological changes, quantity and fluorescence intensity of cells. (A) Morphology of cells (magnification, x100) and (B) fluorescence staining with Hoechst 33258 (magnification, x200). HT, Juglans mandshurica Maxim extracts.

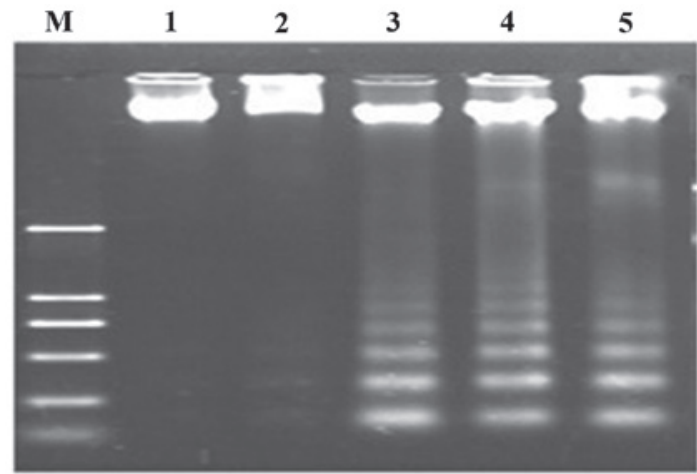

Figure 4. Effect of HT on the apoptosis of HeLa cells assessed using DNA agarose gel electrophoresis. M, DL2000; lane 1, Control; lanes 2-5, 100, 200, 400 and $600 \mu \mathrm{g} / \mathrm{ml}$ of HT, respectively. HT, Juglans mandshurica Maxim extracts.

group, HT significantly inhibited cell proliferation. With increasing HT concentration and time incubation time, the inhibitory effect was gradually and statistically enhanced $(\mathrm{P}<0.01-0.001)$. It was indicated that HT markedly inhibited the proliferation of HeLa cells in a time- and dose-dependent manner. The $\mathrm{IC}_{50}$ was 413.50 (24 h) and $391.30 \mu \mathrm{g} / \mathrm{ml}(48 \mathrm{~h})$ (Table I).

Effect of HT on the necrosis of HeLa cells assessed usingfluorescence staining. It was observed that the percentage of necrotic bodies of HeLa cells increased rapidly in a time-dependent manner following treatment with $600 \mu \mathrm{g} / \mathrm{ml}$ HT for 24 and $48 \mathrm{~h}$. It was observed that HT was capable of inducing apoptosis and necrosis in HeLa cells, as shown in Fig. 3A. Treatment of HeLa cells for 24 and $48 \mathrm{~h}$ with

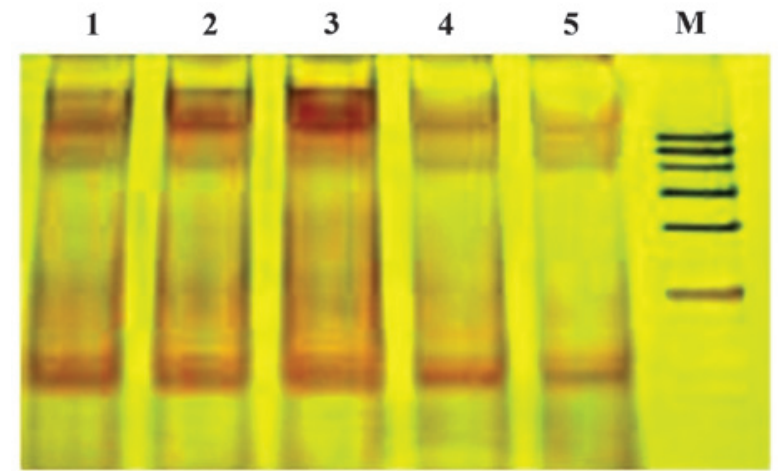

Figure 5. Effect of HT on the telomerase activity in HeLa cells assessed using silver staining. M, DNA marker pBR322-Hae III; lane 1, $600 \mu \mathrm{g} / \mathrm{ml} \mathrm{HT}$ treated for $24 \mathrm{~h}$; lane 2, $600 \mu \mathrm{g} / \mathrm{ml} \mathrm{HT}$ treated for $48 \mathrm{~h}$; lane 3, control; lane $4,300 \mu \mathrm{g} / \mathrm{ml} \mathrm{HT}$ treated for $24 \mathrm{~h}$; lane $5,300 \mu \mathrm{g} / \mathrm{ml} \mathrm{HT}$ treated for $48 \mathrm{~h}$. HT, Juglans mandshurica Maxim extracts.

$600 \mu \mathrm{g} / \mathrm{ml}$ HT resulted in apoptotic cell death. HeLa cells treated with HT and stained with Hoechst 33258 (Fig. 3B) were used to determine the cell death rate. Apoptotic bodies were studied morphologically and included features such as nuclear fragmentation and condensation of chromatin following treatment with $600 \mu \mathrm{g} / \mathrm{ml}$ for 24 and $48 \mathrm{~h}$ as compared with the control group. Nuclear staining with Hoechst 33258 was assessed by fluorescence microscopy. The percentages of necrotic cells induced by $600 \mu \mathrm{g} / \mathrm{ml} \mathrm{HT}$ were 36.80 and $45.71 \%$ following 24 and $48 \mathrm{~h}$ treatment, respectively (Fig. 3).

Effect of HT on the apoptosis of HeLa cells assessed using DNA agarose gel electrophoresis. The induction of apoptosis 
by DNA fragmentation was assessed in HeLa cells incubated with HT. A DNA ladder was observed in HeLa cells treated with 100, 200, 400 and $600 \mu \mathrm{g} / \mathrm{ml}$ HT for $24 \mathrm{~h}$. However, apoptosis was not observed in the control group. The result showed that HT induces apoptosis in HeLa cells and this effect was enhanced with increasing HT concentrations, as shown in Fig. 4.

Effect of HT on the cell cycle of HeLa cells. Compared with the control group (21.2\%), the S phase fraction of HeLa cells treated with 300 and $600 \mu \mathrm{g} / \mathrm{ml} \mathrm{HT}$ for $24 \mathrm{~h}$ was markedly increased to 23 and $28.4 \%$, respectively. S phase arrest was further increased following $48 \mathrm{~h}$ of incubation (37 and $39.4 \%$ ) and exhibited significant differences $(\mathrm{P}<0.05-0.001)$. The G1-phase fraction decreased and the G2-phase fraction increased significantly $(\mathrm{P}<0.05-0.001)$. The results showed that $\mathrm{S}$ phase arrest appeared in HeLa cells treated with HT, in a time- and dose-dependent manner and was greatest at $48 \mathrm{~h}$ (Table II).

Telomerase activity in HeLa cells treated with HT. Compared with the control group, 300 and $600 \mu \mathrm{g} / \mathrm{ml}$ HT inhibited telomerase activity in HeLa cells, and the higher concentration exhibited a marked effect. The inhibitory effect increased in a time- and dose-dependent manner. The results indicated that HT decreased HeLa cell proliferation by inhibiting telomerase activity (Fig. 5).

\section{Discussion}

A large number of bioactive compounds synthesized by marine organisms, plants and microorganisms have been studied for their potential biological activities at the cellular level, which may be employed for novel therapies. The normal growth of the cell depends on strictly controlled stages of the cell cycle (10). According to the present study, HT has the potential to influence the cell cycle stage, and a number of anti-cancer agents have previously been reported to arrest the cell cycle at specific points, and thereby induce apoptotic cell death (11-13). The cell cycle is arrested at the G2 phase when DNA is damaged $(14,15)$. In the present study, HT was shown to have an anti-proliferative effect. The genesis and development of tumors is associated with uncontrolled cell proliferation and evasion of apoptosis, particularly the uncontrolled cell growth caused by multiple gene mutation (16). In addition, numerous statistical outcomes have shown that telomerase activity in the malignant tumors was higher compared with the majority of normal tissue types, and telomerase was involved in the genesis and development of malignant tumors (17). Two mechanisms are important in this context: Telomerase is a reverse transcriptase and may directly interact with telomeres to trigger cell survival. Furthermore, telomerase has a role in the mechanism of DNA damage repair and ensures cell proliferation and survival. These two mechanisms indicate that inhibition of telomerase activity in tumor cells may achieve an anti-tumor effect.

Defects in apoptosis signaling cause tumor cells to exceed the normal life expectancy, which provides an increased opportunity for gene mutations, interfering with differentiation and increasing invasiveness. Apoptotic defects promote tumor cell metastasis and escape recognition by immune cells, including cytotoxic lymphocytes and natural killer cells.
A number of studies have focused on tumor cell apoptosis mechanisms and excessive proliferation inhibition (18-21). The present study indicated that HT significantly inhibited HeLa cell proliferation, and the highest inhibition rate observed was 83.7\%. Results of the trap-silver staining assay showed that HT markedly decreased telomerase activity of HeLa cells and the inhibition occurred in a time- and dose-dependent manner. Thus, the mechanism of the anti-tumor activity of HT may involve the inhibition of telomerase activity in tumor cells. Apoptosis generally features marked morphological changes, including chromatin condensation, nuclear fragmentation and formation of apoptotic bodies. Therefore, it is possible to visually detect apoptosis. Following treatment with HT, the cell walls of HeLa cells disappeared and chromatin condensed. The Hoechst 33258 staining assay showed that HT readily induced apoptosis in HeLa cells as indicated by a bright blue fluorescence staining of the nuclei, while faint blue fluorescence was observed in cells without HT treatment. Furthermore, a DNA ladder, which is characteristic for apoptosis-specific DNA fragmentation, was observed by agarose gel electrophoresis of DNA of HeLa cells incubated with HT. These results indicate that HT markedly induced HeLa cell apoptosis.

Notably, S phase arrest was observed in HeLa cells treated with HT. This increase not only demonstrated the effect of HT on cellular activity, but also reflected a time- and dose-dependent pattern for HeLa cell cycle arrest in S phase. The release of DNA from cells during late apoptosis and necrosis indicated that the nuclear DNA contents decreased in the cells (22). The distribution of the DNA content detected by flow cytometry may thus be able to indicate the number of apoptotic cells. The preliminary results showed that HT blocked HeLa cells in S phase.

In conclusion, the current study, evidenced that HT has a marked effect on HeLa cells in vitro. It markedly inhibited telomerase activity in HeLa cells, blocked cells in S phase and induced apoptosis in tumor cells in a time- and dose-dependent manner. However, genesis and development of tumors are complicated processes, which are proceed via a variety of pathways. The complex mechanism of the anti-tumor and apoptosis-inducing effect of HT requires further study.

\section{Acknowledgements}

The present study was supported by the Beijing Municipal Science and Technology Commission of P.R. China (no. 60217289).

\section{References}

1. Chen HC, Schiffman M, Lin CY, Pan MH, You SL, Chuang LC, Hsieh CY, Liaw KL, Hsing AW and Chen CJ; CBCSP-HPV Study group: Persistence of type-specific human papillomavirus infection and increased long-term risk of cervical cancer. J Natl Cancer Inst 103: 1387-1396, 2011.

2. Parkin DM: The global health burden of infection-associated cancers in the year 2002. Int J Cancer 118: 3030-3044, 2006.

3. Kaefer CM and Milner JA: The role of herbs and spices in cancer prevention. J Nutr Biochem 19: 347-361, 2008.

4. Sun ML, Wang YM, Song ZQ and Fang GZ: Insecticidal activities and active components of the alcohol extract from green peel of Juglans mandshurica. J Forestry Res 18: 62-64, 2007.

5. Zhou YY and Wang D: Advances in study on the compounds of Juglans mandshurica Maxim. J Chin Mod Tradit Chin Med 3: 8-10, 2007 (In Chinese). 
6. Li Y, Xin N, Li YJ and Zhang JY: Investigation into anti-tumor and immunomodulatory effects of Juglans mandshurica maxim extracts (HT). Transactions Beijing Inst Technol 31: 618-621, 2011 (In Chinese).

7. Li SZ, Wang YC, Jiang DF and Wang Y: Screening effective part of qinglongyi and Walnut sticks on anti-tumor by Brine Shrimp Lethelity Bioassay. Northwest Pharm J 15: 114, 2006 (In Chinese).

8. Guo JH, Cui LM, Li SH, Liu L, He RH and Liu B: Inhibitory effects and immunoregulation of Juglans mandshurica maxim extract on $\mathrm{S}_{180}$ mouse sarcoma. J Jilin Univ (Med Ed) 33: 286-289, 2007 (In Chinese).

9. Kim SH, Lee KS, Son JK, Je GH, Lee JS, Lee CH and Cheong CJ: Cytotoxic compounds from the roots of Juglans mandshurica. J Nat Prod 61: 643-645, 1998.

10. Murray AW: Recycling the cell cycle: cyclins revisited. Cell 116: 221-234, 2004

11. Lu YJ, Yang SH, Chien CM, Lin YH, Hu XW, Wu ZZ, Wu MJ and Lin SR: Induction of G2/M phase arrest and apoptosis by a novel enediyne derivative, THDB, in chronic myeloid leukemia (HL-60) cells. Toxicol in Vitro 21: 90-98, 2007.

12. Gamet-Payrastre L, Li P, Lumeau S, Cassar G, Dupont MA, Chevolleau S, Gasc N, Tulliez J and Tercé F: Sulforaphane, a naturally occurring isothiocyanate, induces cell cycle arrest and apoptosis in HT29 human colon cancer cells. Cancer Res 60: 1426-1433, 2000.

13. Fujimoto K, Hosotani R, Doi R, Wada M, Lee JU, Koshiba T, Miyamoto Y, Tsuji S, Nakajima Y and Imamura M: Induction of cell-cycle arrest and apoptosis by a novel retinobenzoic-acid derivative, TAC-101, in human pancreatic-cancer cells. Int J Cancer 81: 637-644, 1999.
14. Taylor WR and Stark GR: Regulation of the G2/M transition by p53. Oncogene 20: 1803-1815, 2001.

15. Luk SC, Siu SW, Lai CK, Wu YJ and Pang SF: Cell cycle arrest by a natural product via G2/M checkpoint. Int J Med Sci 2: 64-69, 2005.

16. Xu HL, Yu XF, Qu SC, Zhang R, Qu XR, Chen YP, Ma XY and Sui DY: Anti-proliferative effect of Juglone from Juglans mandshurica Maxim on human leukemia cell HL-60 by inducing apoptosis through the mitochondria-dependent pathway. Eur J Pharmacol 645: 14-22, 2010.

17. Blasco MA: Telomerase beyond telomeres. Nat Rev Cancer 2: 627-633, 2002.

18. Shi H and Ding ZS: Study progress of the chemical composition and pharmacological effects of the pecan species. Chin Tradit Patent Med 31: 924-928, 2009.

19. Chen FH and Tang WM: Studies on the Constituents and Biological Activity of the Bark of Juglans regia. Natural Product Research and Development 20: 16-18, 2008.

20. Zhang YL, Zhan M, Pan YF, Fan W, Li HZ and Huang QS: Study on the contribution to the cytokines of the carya bark decoction to the BALb/c tumor-bearing mice. Strait Pharm J 21: 40-43, 2009.

21. Han LK, Li W, Narimatsu S, Liu LJ, Fu HW, Okuda H and Koike K: Inhibitory effects of compounds isolated from fruit of Juglans mandshurica on pancreatic lipase. J Nat Med 61: 184-186, 2007.

22. Shi YY, Li H and Yang SJ: Induction of apoptosis by panax quinquefolium effective parts (PQEP) on K562 cells. Chin Pharmacol Bull 21: 1494-1497, 2005. 